Article

\title{
Transcriptional Analysis-Based Alterations Affecting Neuritogenesis of the Peripheral Nervous System in Psoriasis
}

\author{
Dóra Romhányi ${ }^{1}$, Kornélia Szabó ${ }^{1,2,3}$, Lajos Kemény ${ }^{1,2,3}$ (D) Endre Sebestyén ${ }^{4}$ and Gergely Groma ${ }^{1,3, *(1)}$ \\ 1 Department of Dermatology and Allergology, University of Szeged, H-6720 Szeged, Hungary; \\ romhanyidora9411@gmail.com (D.R.); szabo.kornelia@med.u-szeged.hu (K.S.); \\ kemeny.lajos@med.u-szeged.hu (L.K.) \\ 2 Hungarian Centre of Excellence for Molecular Medicine-University of Szeged Skin Research \\ Group (HCEMM-USZ Skin Research Group), University of Szeged, H-6720 Szeged, Hungary \\ 3 Eötvös Loránd Research Network, MTA-SZTE Dermatological Research Group, H-6720 Szeged, Hungary \\ 4 1st Department of Pathology and Experimental Cancer Research, Semmelweis University, \\ H-1085 Budapest, Hungary; endre.sebestyen@gmail.com \\ * Correspondence: groma.gergely@med.u-szeged.hu
}

check for updates

Citation: Romhányi, D.; Szabó, K.; Kemény, L.; Sebestyén, E.; Groma, G. Transcriptional Analysis-Based

Alterations Affecting Neuritogenesis of the Peripheral Nervous System in Psoriasis. Life 2022, 12, 111. https:// doi.org/10.3390/life12010111

Academic Editor: Ivone Jakasa

Received: 16 November 2021

Accepted: 4 January 2022

Published: 13 January 2022

Publisher's Note: MDPI stays neutral with regard to jurisdictional claims in published maps and institutional affiliations.

Copyright: (C) 2022 by the authors. Licensee MDPI, Basel, Switzerland. This article is an open access article distributed under the terms and conditions of the Creative Commons Attribution (CC BY) license (https:// creativecommons.org/licenses/by/ $4.0 /)$.

\begin{abstract}
An increasing amount of evidence indicates the critical role of the cutaneous nervous system in the initiation and maintenance of psoriatic skin lesions by neurogenic inflammation. However, molecular mechanisms affecting cutaneous neurons are largely uncharacterized. Therefore, we reanalyzed a psoriatic RNA sequencing dataset from published transcriptome experiments of nearly 300 individuals. Using the Ingenuity Pathway Analysis software, we associated several hundreds of differentially expressed transcripts (DETs) to nervous system development and functions. Since neuronal projections were previously reported to be affected in psoriasis, we performed an in-depth analysis of neurite formation-related process. Our in silico analysis suggests that SEMA-PLXN and ROBO-DCC-UNC5 regulating axonal growth and repulsion are differentially affected in non-lesional and lesional skin samples. We identified opposing expressional alterations in secreted ligands for axonal guidance signaling (RTN4/NOGOA, NTNs, SEMAs, SLITs) and non-conventional axon guidance regulating ligands, including WNT5A and their receptors, modulating axon formation. These differences in neuritogenesis may explain the abnormal cutaneous nerve filament formation described in psoriatic skin. The processes also influence T-cell activation and infiltration, thus highlighting an additional angle of the crosstalk between the cutaneous nervous system and the immune responses in psoriasis pathogenesis, in addition to the known neurogenic pro-inflammatory mediators.
\end{abstract}

Keywords: psoriasis; cutaneous nervous system; axon development; myelination

\section{Introduction}

Psoriasis is a chronic inflammatory skin disease affecting approximately $1-3 \%$ of the human population worldwide. It is characterized mainly as an abnormal skin reaction to various internal and external stimuli, leading to keratinocyte hyperproliferation and chronic immunological responses [1]. Despite the large amount of work, the exact pathomechanism of psoriasis remains unclear. Therefore, a deeper understanding of the disease-causing alterations is important to develop new treatment options that not only treat the existing symptoms but also interfere with their development.

In psoriasis, the macroscopically healthy-looking non-lesional (NL) skin already carries alterations that in combination with various abiotic and biotic stimuli lead to the appearance of symptoms [2,3]. One of the widely known characteristics of the NL skin is the Köbner phenomenon, the development of lesions in response to mechanical provocations or stress [4] due to elevated immune response and increased keratinocyte proliferation [5,6]. External, potentially dangerous stimuli are not only sensed by keratinocytes but also by cutaneous neurons, among other cells. Skin cells become activated by these insults, produce 
pro-inflammatory cytokines [7], and may also activate and modulate the neuronal functions of nociceptors [8]. An example of this is an altered thermosensation in psoriatic tissues [9].

Peripheral nervous system (PNS) abnormalities resulting in the loss of sensory abilities could lead to the remission of psoriatic lesions, including, I. superficial cutaneous nerve injury [10], II. poliomyelitis-associated flaccid paralysis [11], III. loss of intercostobrachial nerve function [12], IV. permanent severance of the left lateral cutaneous nerve [13], V. traumatic unilateral brachial plexus palsy [14], VI. loss of finger sensation due to peripheral denervation [15] and VII. partial axonal and demyelinating neuropathy [16]. Damages affecting the central nervous system (and thereby also the PNS) e.g., hemiparesis [17] and hemiplegia [18] or stroke [19] were reported to cause the clearance of psoriatic plaques at the neuronal dysfunction-affected peripheral areas. Moreover, in cases when the nerve injury-associated anesthesia was only temporary, psoriatic symptoms reappeared following nerve function recovery [14]. These case reports were recently summarized in depth by Bi Qin and colleagues [20] and by Tian Hao Zhu and coworkers [21].

Apart from the nervous system-related injuries, several case series showed nearcomplete remission of psoriatic lesions following botulinum toxin treatment $[22,23]$ that further supports the role of the nervous system both in the formation, as well as in the maintenance of psoriatic plaques. In a psoriasiform animal model, botulinum toxin treatment was suggested to exert its effect through the inhibition of neuropeptides [24]. In 1986, researchers suggested the influence of cutaneous neurons and neuro-immune factors in the pathogenesis of psoriasis [25]. Since then, numerous studies indicated the role of neuropeptides both in the inflammatory and the proliferative processes in psoriasis pathogenesis. As a result, we may consider psoriasis, at least in part, as a neurogenic inflammatory disease [26]. Studies reported increased expression of several neuropeptides in the lesional (L) skin, including CGRP (calcitonin gene-related protein) [27,28], NGF (nerve growth factor) [29], SP (substance P) [30,31], VIP (vasoactive intestinal peptide) [32]. Apart from their neural functions, these molecules also display pro-inflammatory activities and thereby may contribute to inflammation [33], highlighting an important role of the nervous system in psoriasis pathomechanism.

The majority of psoriatic patients are troubled by itch at their L skin [34,35]. In these areas, neurogenic pro-inflammatory mediators, e.g., CGRP, NGF, and SP can contribute to itching (pruritus) development [36-38]. Thus, patients may also suffer from aching, burning, cramping, stinging, tenderness, and tingling at the L areas [39], suggesting that cutaneous neuronal sensation mechanisms are affected at multiple levels.

While our knowledge of how neurons affect the immune system is continuously increasing, little is known about how the cutaneous nervous system itself is affected in psoriasis. Several large-scale studies, including proteomics [40,41], RNA microarray [42], and high throughput sequencing (HTS) [43,44], GWAS [45], and DNA methylation profiling [46] analyses have been performed to gain a deeper insight into the pathomechanism of the disease [47]. However, our knowledge of the involvement of the peripheral and the cutaneous nervous system in psoriasis remains limited.

Therefore we took advantage of the transcriptome sequencing results of three major published psoriatic datasets and reanalyzed the combined data by using the Ingenuity Pathway Analysis software for downstream enrichment analysis [43,44,48]. Using an unbiased annotation, we found 347 and 885 differentially expressed transcripts (DETs) in relation to the nervous system in NL and L skin samples, respectively. These DETs were associated with nervous system development and functions, in particular, with neuritogenesis-regulating mechanisms. This may seem peculiar, knowing that the cell body of neurons are not located in the skin. However, earlier studies indicate that massive RNA transport and translation take place in the axons that are located at cutaneous tissues $[49,50]$. Therefore, we decided to focus on these mechanisms by analyzing neuritogenesis-related alterations in depth. 


\section{Materials and Methods}

\subsection{Criteria for Combining the Transcriptome Sequencing Data of from Three Published Psoriatic Datasets}

To identify general alterations in psoriasis and to avoid any potentially non-disease related associations and differences, randomly engaged individuals of chronic plaque psoriatic patient and healthy donors were involved in the three studies $[43,44,48]$ of which the combined database was generated from. For inclusion criteria no preference of gender, age (apart from $>18$ ), or Psoriasis Area Severity Index scores (min. 1\% of total body surface area) was put forward in any of the three studies, of which the RNA sequencing data were collected from. Similarly, skin punch biopsies $(6 \mathrm{~mm})$ were collected from various regions of the body (hip, buttlock, thigh, back, arm, flank, abdomen, elbow). A wash out period of 1 week for patients on topical anti-psoriatic treatments and 2 weeks for those on any systemic anti-psoriatic treatments was set as general criteria prior to biopsy collection.

\subsection{RNA Sequencing Data Processing}

The RNA sequencing datasets from three papers were uniformly reprocessed [43,44,48]. We downloaded the data from SRA (Sequence Read Archive, https: / /www.ncbi.nlm.nih.gov/ sra, accessed on 15 November 2021) with study ID accession numbers SRP035988, SRP050971, and SRP055813 using SRA-tools (version 2.9.2, https:/ / github.com/ncbi/sra-tools, accessed on 15 November 2021) and reprocessed all available samples. We quantified transcript level expression using Kallisto [51] (version 0.43.0) and the full GENCODE [52] v27 transcriptome annotation, available at https:/ / www.gencodegenes.org (accessed on 15 November 2021). Kallisto was run with the following options: -bias -single -l 120 -s 20 -b 100.

\subsection{Differential Expression Analysis}

Transcript-level length-scaled TPM (Transcripts Per Million) expression estimates from Kallisto were imported into the R statistical environment (version 3.4.3, https: / /www.rproject.org; accessed on 15 November 2021), using the tximport [53] package (version 1.6.0). The data were TMM (trimmed mean of M-values) normalized and voom transformed. We used edgeR [54] (version 3.20.9) for the TMM normalization and the voomWithQualityWeights() function from limma $[55,56]$ (version 3.34.9) for the voom transformation. We decided to use voomWithQualityWeights() to combine transcript observation-level weights with sample-specific weight, as we did not want to discard samples with lower quality, but preferred to downweigh them in the analysis. Limma was also used to test for differential expression between lesional and non-lesional, lesional and healthy, or non-lesional and healthy sample groups. A linear model was fitted with the limma lmFit function, and the moderated $t$-statistics was calculated with the eBayes function. Transcripts were defined as differentially expressed if they had an FDR [56,57] (false discovery rate) corrected $p$-value $<0.05$ and an absolute log2 fold-change larger than 1.

\subsection{Functional Annotation, Enrichment Analysis, and Statistics}

Differentially expressed transcripts (DETs) from NL vs. H and L vs. H comparison were analyzed using Ingenuity Pathway Analysis (IPA) software (IngenuityH Systems, www.ingenuity.com; accessed on 15 November 2021) to identify pathways that are enriched. DET sets were mapped to the HUGO gene symbols within IPA software and those that did not map to any HUGO gene were discarded. For "Diseases and Biological functions" annotation, the $p$-value was calculated using Fisher's exact test [58] to measure the significance of DET enrichment of a given pathway. For the Gene Ontology enrichment analysis and visualization (Gorilla) tool, the enrichment analysis $p$-value was calculated according to the mHG or HG model [59]; $p$-value correction for multiple testing was done according to the Benjamini and Hochberg method [60] (FDR correction). Enrichment was defined as: $(b / n) /(B / N)$, where $N$ : total number of genes, B: total number of genes associated with a given specific GO term, n: number of genes in the top of the user's input list or in the target set when appropriate, $b$ : number of genes in the intersection. 


\section{Results}

\subsection{Peripheral Nervous System-Associated Transcript Expression Alterations in Psoriasis}

Based on our transcriptome analysis, 2681 transcripts showed altered expression level in the NL and healthy $(\mathrm{H})$ skin comparison (Supplementary Table S1A, whereas the number of transcripts with altered expression in L vs. H skin was 12314 (Supplementary Table S1B).

Ingenuity Pathway Analysis (IPA) software identified DETs coded by 347 and 885 genes in association with nervous system development and function in NL and L skin, respectively (Supplementary Table S1C,D). These DETs are predicted to affect neuronal morphogenesis, including neuritogenesis, which represented the most specific group in the analysis (Table 1 and Supplementary Table S1E,F).

Table 1. Functional annotation of nervous system related DETs in non-lesional and lesional psoriatic skin. (H: healthy, L: lesional, NL: non-lesional skin).

\begin{tabular}{|c|c|c|c|c|}
\hline Categories & Functions & Comparison & $p$-Value & Number of Molecules \\
\hline \multirow{2}{*}{ Nervous System Development and Function } & \multirow{2}{*}{$\begin{array}{l}\text { Morphology of } \\
\text { nervous system }\end{array}$} & NL vs. H & $4.11 \mathrm{E}-17$ & 236 \\
\hline & & L vs. H & $5.28 \mathrm{E}-32$ & 637 \\
\hline \multirow{2}{*}{$\begin{array}{c}\text { Nervous System Development and Function, } \\
\text { Neurological Disease }\end{array}$} & \multirow{2}{*}{$\begin{array}{l}\text { Abnormal } \\
\text { morphology of } \\
\text { nervous system }\end{array}$} & NL vs. H & 4.95E-13 & 188 \\
\hline & & L vs. H & $2.80 \mathrm{E}-20$ & 495 \\
\hline \multirow{2}{*}{$\begin{array}{c}\text { Nervous System Development and Function, } \\
\text { Tissue Morphology }\end{array}$} & \multirow{2}{*}{$\begin{array}{l}\text { Morphology of } \\
\text { nervous tissue }\end{array}$} & NL vs. H & 1.11E-12 & 165 \\
\hline & & L vs. H & $5.25 \mathrm{E}-22$ & 439 \\
\hline \multirow{2}{*}{$\begin{array}{l}\text { Nervous System Development and Function, } \\
\text { Organismal Development, Tissue Development }\end{array}$} & \multirow{2}{*}{$\begin{array}{l}\text { Morphogenesis of } \\
\text { nervous tissue }\end{array}$} & NL vs. H & $4.70 \mathrm{E}-10$ & 144 \\
\hline & & L vs. H & $4.46 \mathrm{E}-22$ & 405 \\
\hline \multirow{2}{*}{$\begin{array}{l}\text { Cell Morphology, Cellular Assembly and } \\
\text { Organization, Cellular Development, Cellular } \\
\text { Function and Maintenance, Cellular } \\
\text { Growth and Proliferation, Nervous System } \\
\text { Development and Function, Organismal } \\
\text { Development, Tissue Development }\end{array}$} & \multirow[t]{2}{*}{ Neuritogenesis } & NL vs. H & $5.26 \mathrm{E}-10$ & 142 \\
\hline & & L vs. H & $6.62 \mathrm{E}-22$ & 399 \\
\hline \multirow{2}{*}{$\begin{array}{l}\text { Cell Morphology, Cellular Development, Cellular } \\
\text { Growth and Proliferation, Nervous System } \\
\text { Development and Function, Organismal } \\
\text { Development, Tissue Development }\end{array}$} & \multirow{2}{*}{$\begin{array}{l}\text { Morphogenesis of } \\
\text { neurons }\end{array}$} & NL vs. H & $6.60 \mathrm{E}-10$ & 143 \\
\hline & & L vs. H & $6.85 \mathrm{E}-22$ & 403 \\
\hline \multirow{2}{*}{$\begin{array}{c}\text { Cellular Development, Cellular Growth and } \\
\text { Proliferation, Nervous System Development and } \\
\text { Function, Tissue Development }\end{array}$} & \multirow{2}{*}{$\begin{array}{l}\text { Development of } \\
\text { neurons }\end{array}$} & NL vs. H & 1.12E-09 & 177 \\
\hline & & L vs. H & $2.14 \mathrm{E}-24$ & 517 \\
\hline
\end{tabular}

\subsection{Differentially Expressed Transcripts Affecting Axon-Related Alterations in Non-Lesional and} Lesional Psoriatic Skin

Since only neurites penetrate the skin, we wanted to gain further insight into how neuron projections are likely to be affected in the skin. For this, we performed gene ontology (GO) functional enrichment analysis using neuron projection GO:0043005 as a background in Gorilla (Gene Ontology enrichment analysis and visualization tool; accessed on 15 November 2021.) on the neuritogenesis-associated DETs from the original IPA analysis. This analysis revealed biological processes linked to the regulation of neuron projection development and the semaphorin-plexin signaling pathway. According to our results, these pathways are likely to be affected already in the NL skin, and to a greater extent in L samples, as suggested by a higher number of DETs in the latter group (Table 2 and Supplementary Table S1G,H). 
Table 2. Gene ontology (GO) functional enrichment analysis of DETs associated with neuritogenesis in non-lesional and lesional skin. (H: healthy, L: lesional, NL: non-lesional skin).

\begin{tabular}{|c|c|c|c|c|c|}
\hline GO Term & Description & Comparison & $p$-Value & FDR q-Value & $\begin{array}{c}\text { Enrichment } \\
(\mathrm{N}, \mathrm{B}, \mathrm{n}, \mathrm{b})\end{array}$ \\
\hline \multirow{2}{*}{ GO:0010975 } & \multirow{2}{*}{$\begin{array}{l}\text { Regulation of } \\
\text { neuron } \\
\text { projection } \\
\text { development }\end{array}$} & NL vs. H & $1.98 \mathrm{E}-4$ & $2.74 \mathrm{E}-2$ & $\begin{array}{c}1.72(1442, \\
229,139,38)\end{array}$ \\
\hline & & L vs. H & $6.66 \mathrm{E}-10$ & $2.79 \mathrm{E}-7$ & $\begin{array}{c}1.64(1594 \\
260,389,104)\end{array}$ \\
\hline \multirow{2}{*}{ GO:0045664 } & \multirow{2}{*}{$\begin{array}{l}\text { Regulation of } \\
\text { neuron } \\
\text { differentiation }\end{array}$} & NL vs. H & $2.68 \mathrm{E}-4$ & 3.35E-2 & $\begin{array}{c}1.67(1442 \\
249,139,40)\end{array}$ \\
\hline & & L vs. H & $6.63 \mathrm{E}-11$ & 4.07E-8 & $\begin{array}{c}1.64(1594 \\
285,389,114)\end{array}$ \\
\hline \multirow{2}{*}{ GO:0071526 } & \multirow{2}{*}{$\begin{array}{l}\text { Semaphorin- } \\
\text { plexin signaling } \\
\text { pathway }\end{array}$} & NL vs. H & $4.09 \mathrm{E}-4$ & 4.07E-2 & $\begin{array}{c}5.19(1442,12 \\
139,6)\end{array}$ \\
\hline & & L vs. H & 2.3E-5 & $1.37 \mathrm{E}-3$ & $\begin{array}{c}2.96(1594,18, \\
389,13)\end{array}$ \\
\hline
\end{tabular}

In addition, neuron projection morphogenesis, development, and guidance (Table 3 and Supplementary Table S1I,J) were predicted to be affected only in psoriatic lesions (Table 4 and Supplementary Table S1K,L). Among axon formation-associated regulatory processes, negative regulation of axonogenesis and axon guidance are predicted to be affected in psoriatic lesions (Table 4 and Supplementary Table S1K,L).

Table 3. Gene ontology (GO) functional enrichment analysis of DETs associated with neuritogenesis reveals neuron projection-related biological processes in lesional but not in non-lesional skin. (H: healthy, L: lesional).

\begin{tabular}{|c|c|c|c|c|c|}
\hline GO Term & Description & Comparison & $p$-Value & FDR q-Value & Enrichment $(N, B, n, b)$ \\
\hline GO:0048812 & Neuron projection morphogenesis & \multirow{5}{*}{ Lvs. H } & $2.94 \mathrm{E}-10$ & $1.43 \mathrm{E}-7$ & $1.96(1594,138,389,66)$ \\
\hline GO:0097485 & Neuron projection guidance & & 8.37E-7 & 9.17E-5 & $1.78(1594,124,389,54)$ \\
\hline GO:0031175 & Neuron projection development & & $9.31 \mathrm{E}-7$ & $9.74 \mathrm{E}-5$ & $1.68(1594,159,389,65)$ \\
\hline GO:0010976 & $\begin{array}{l}\text { Positive regulation of neuron } \\
\text { projection development }\end{array}$ & & $3.15 \mathrm{E}-6$ & $2.54 \mathrm{E}-4$ & $1.69(1594,141,389,58)$ \\
\hline GO:0010977 & $\begin{array}{l}\text { Negative regulation of neuron } \\
\text { projection development }\end{array}$ & & $9.99 \mathrm{E}-5$ & $4.76 \mathrm{E}-3$ & $1.74(1594,87,389,37)$ \\
\hline
\end{tabular}

Table 4. Gene ontology (GO) functional enrichment analysis of DETs associated with neuritogenesis reveals axon formation-related biological processes only in lesional psoriatic skin. (H: healthy, L: lesional).

\begin{tabular}{|c|c|c|c|c|c|}
\hline GO Term & Description & Comparison & $p$-Value & FDR q-Value & Enrichment (N, B, n, b) \\
\hline GO:0050770 & Regulation of axonogenesis & \multirow{8}{*}{ L vs. H } & $6.36 \mathrm{E}-7$ & $7.32 \mathrm{E}-5$ & $1.89(1594,102,389,47)$ \\
\hline GO:0007411 & Axon guidance & & 8.37E-7 & $9.06 \mathrm{E}-5$ & $1.78(1594,124,389,54)$ \\
\hline GO:1902668 & Negative regulation of axon guidance & & $8.36 \mathrm{E}-5$ & $4.2 \mathrm{E}-3$ & $3.00(1594,15,389,11)$ \\
\hline GO:0048843 & $\begin{array}{l}\text { Negative regulation of axon } \\
\text { extension involved in axon guidance }\end{array}$ & & $9.41 \mathrm{E}-5$ & $4.56 \mathrm{E}-3$ & $3.15(1594,13,389,10)$ \\
\hline GO:0050771 & Negative regulation of axonogenesis & & $2.61 \mathrm{E}-4$ & 1.07E-2 & $2.00(1594,45,389,22)$ \\
\hline GO:0008045 & Motor neuron axon guidance & & 6.07E-4 & $2.21 \mathrm{E}-2$ & $2.73(1594,15,389,10)$ \\
\hline GO:0048841 & $\begin{array}{l}\text { Regulation of axon extension } \\
\text { involved in axon guidance }\end{array}$ & & 6.07E-4 & $2.2 \mathrm{E}-2$ & $2.73(1594,15,389,10)$ \\
\hline GO:1902667 & Regulation of axon guidance & & $9.35 \mathrm{E}-4$ & $3.19 \mathrm{E}-2$ & $2.50(1594,18,389,11)$ \\
\hline
\end{tabular}


Axon formation is strongly associated with Schwann cell myelination in the peripheral nervous system. Despite that functional enrichment analysis did not reveal any associated processes, skin tissue expression analysis (tissues.jensenlab.org; accessed on 15 November 2021) integrated into the STRING database (version:11.5; accessed on 15 November 2021) revealing certain associations. Four molecules (MBP, MPZ, PMP22, and EGR2) out of the DETs coded by 347 genes in NL were assigned to Schwann cells (BTO:0001220, 4 of 6 molecules), and another four (MBP, MPZ, PMP22, and RTN4) to myelin (BTO:0000894, 4 of 6 molecules). A similar analysis also pointed out four (MBP, MPZ, EGR2, and PRX) Schwann cell-associated molecules in L skin samples (out of the DETs coded by 885 genes), while myelin-related molecules were MBP, MPZ, PLP1, and RTN4 (Supplementary Table $\mathrm{S} 1 \mathrm{M}$ ). Our analysis suggests that a common molecule that emerges is RTN4 (also known as Nogo), thus myelin-associated inhibitory regulation of axon formation via RTN4 appears to be a common mechanism both in NL and L skin samples.

\subsection{Semaphorin-Plexin Signaling, An Important Regulator of Axon Formation, Is Differentially} Affected in Non-Lesional and Lesional Psoriatic Skin

Since both IPA and GOrilla enrichment analysis suggested that Semaphorin-Plexin signaling is affected (Semaphorin Neuronal Repulsive Signaling Pathway: $p$-value NL vs. $\mathrm{H}^{=1.52 E-03}$ and $p$-value Lv. $\mathrm{H}=1.45 \mathrm{E}-02$ and Table 2., respectively) in psoriasis pathogenesis, we analyzed these pathways in depth. Type 3 semaphorins (Sema3) play a role in neurite formation by regulating axon attraction and repulsion. Among the Sema 3 family members that inhibit axon extension, we found DETs coded by Sema3B and Sema3F genes both in NL and L skin, while in L skin, we also detected Sema3D, Sema3E, and Sema3G expression (Figure 1 and Supplementary Table S1N). Sema3A is not affected by DETs in NL or L skin. Among semaphorin3 receptors and coreceptors, L1CAM, Nrp1and PlxnD1 are only affected by DETs in NL skin, while in L samples gene expressional differences are associated with Nrp2 and PlxnA3 (Figure 1.). Transcripts of downstream signaling molecules Fyn, Crpm1, Mapk3, Mknk1, and Paks are differentially expressed both in NL and L skin. Fes and AKT expression are altered only in NL, while DETs of eIF4E, Farp2, Limk2, MsrB1, PI3K, and Rnd1 are present in lesions (Figure 1). These abnormalities may suggest that axon repulsion and the negative regulation of axon attraction is likely to be highly affected in L in contrast to NL skin, where PI3K-mediated negative regulation of axon attraction does not seem to play a role when compared to H skin samples.

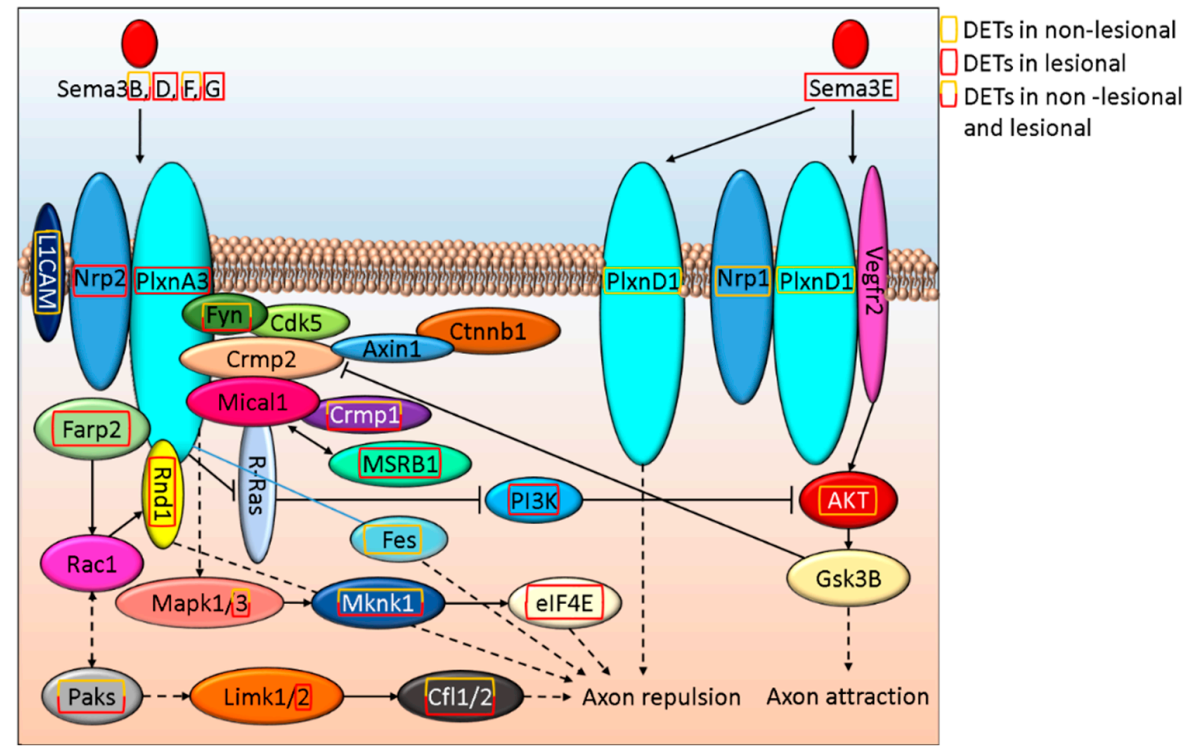

Figure 1. In silico model of how Sema3 signaling alterations regulate axon morphogenesis in NL and L psoriatic skin. 
Sema4D is important in axon regeneration not only by modulating axon elongation but also by inhibiting neuron myelination [61]. SEMA4D encoding DETs are present in L but not in NL skin. Sema4D cell surface receptors (PlxnD1 and ErbB2), as well as downstream signaling proteins (Paks, Cfl1, and Cfl29) expression are altered in NL and L skin. Whereas in NL skin, AKT, Arhgef11, and RAF, while in L samples Mlc1, PI3K, Rnd1, Rock2, and Shc are affected by DETs (Figure 2 and Supplementary Table S1O).

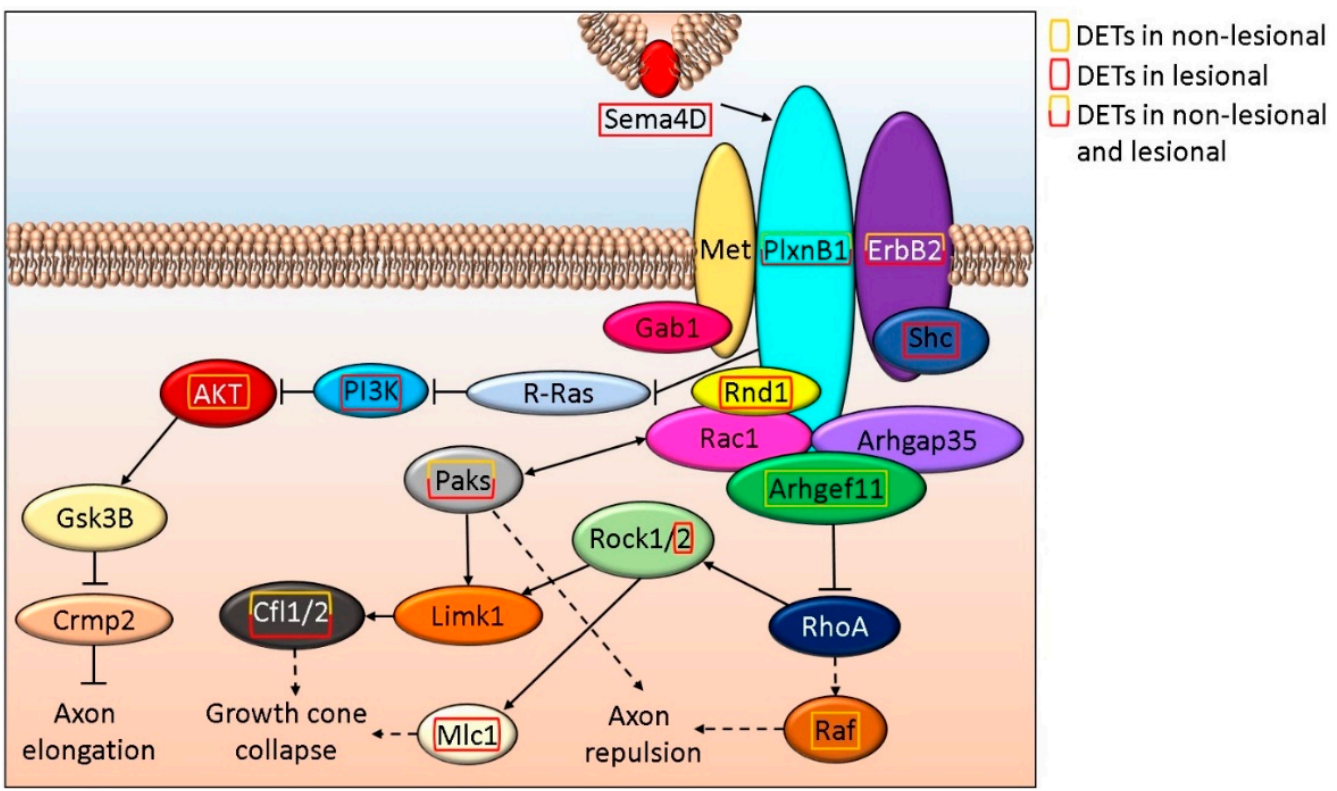

Figure 2. Schematic in silico model of the role Sema4D signaling play in axon elongation/repulsion in NL and L skin.

Sema6A and 6D gene expression is affected in lesions that share receptors of Sema3A, as well as CSPG, the receptor of Sema5A. These alterations may also affect axon repulsion. The schematic in silico model of the potential crosstalk between Sema3-Sema4-Sema5Sema6 signaling is shown in Supplementary Figure S1 and Table S1P, while Supplementary Figure S2 and Table S1Q shows the interaction of Sema4 and Sema7A signaling, which only affected in L samples.

\subsection{ROBO-DCC-UNC5 Signaling Regulates Axon Formation and Differentially Affected in Non-Lesional and Lesional Psoriatic Skin}

Axon dynamics is also regulated through Slit and Ntn signaling via Robo and Dcc, respectively. Slit and Ntn signaling via Robo and Dcc were found as part of the general canonical signaling pathway term Axonal Guidance Signaling that also included Wnt5a and semaphorins and were suggested to be affected both in NL and Lesional skin ( $p$-value NL vs. $\mathrm{H}=3.21 \mathrm{E}-5$ and $p$-value $\mathrm{L}_{\mathrm{L} \text {. } \mathrm{H}}=5.03 \mathrm{E}-06$, respectively). SLIT2 and its receptor ROBO2 are affected only in L skin, while ROBO1 expression is altered in NL and L samples (Figure 3 and Supplementary Table S1R). The expression of NTN1, as well as its receptors DCC (Figure 3) and UNC5A (Figure 4 and Supplementary Table S1S) are affected in L but not in NL skin, where only some of the downstream proteins may be differentially expressed. 


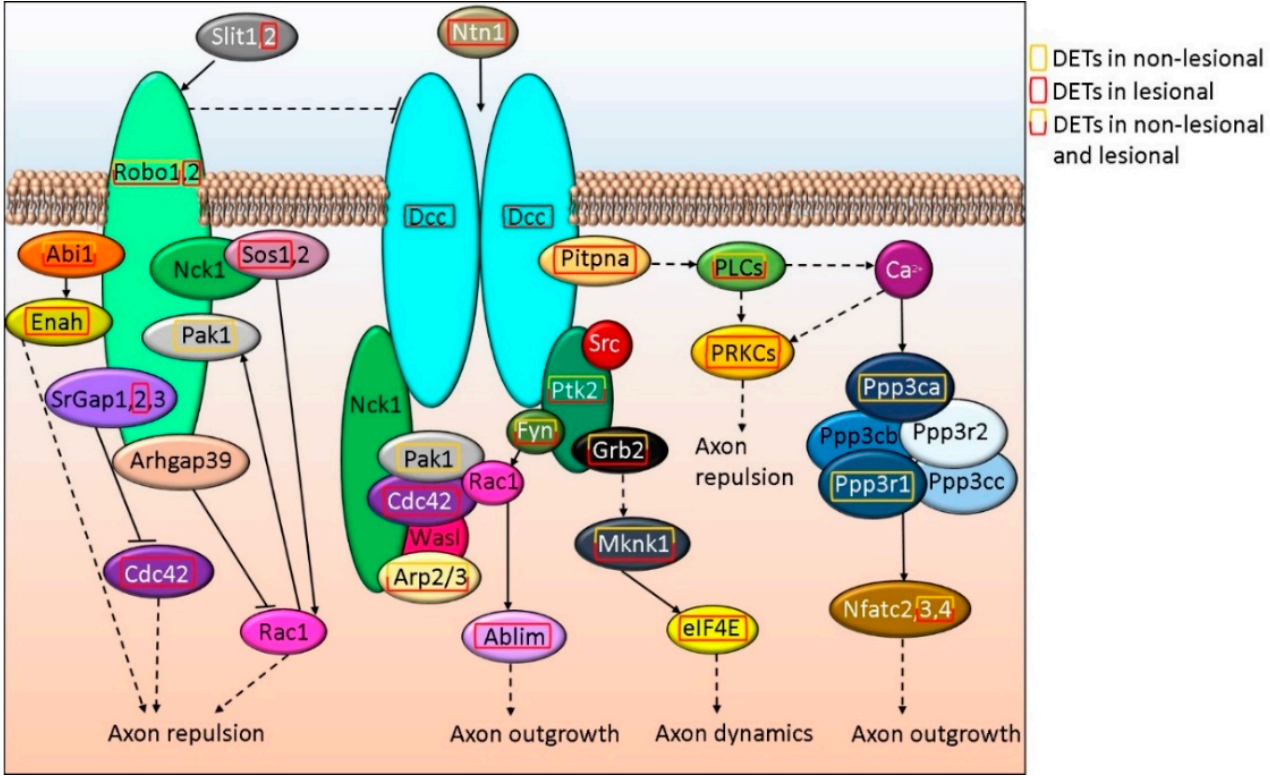

Figure 3. Schematic in silico model of axon outgrowth/repulsion regulation via Robo-DCC signalingrelated alterations in NL and L skin.
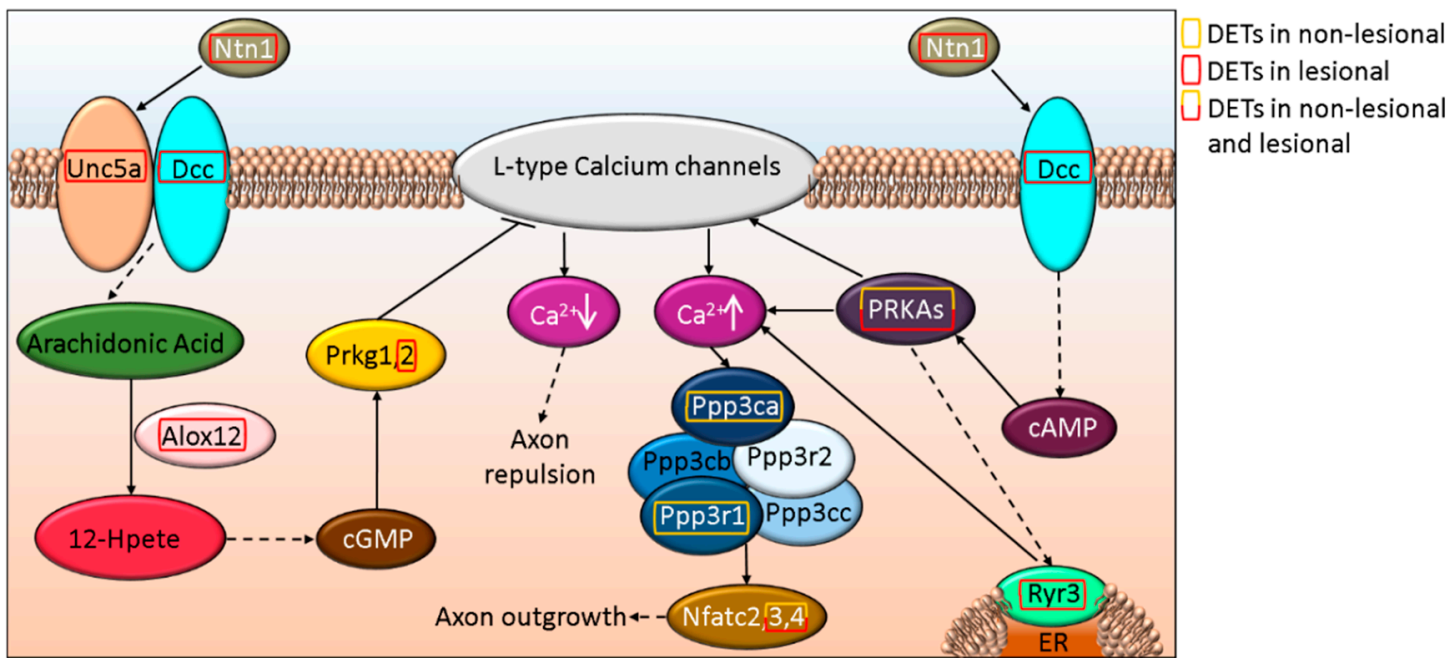

Figure 4. Schematic in silico model of axon outgrowth/repulsion regulation by UNC5A-DCC signaling-related alterations in NL and L skin.

\subsection{Disturbed WNT5A Signaling Potentially Affect Cutaneous Axon Growth in Psoriasis}

We found that WNT5A is affected in psoriatic lesions, and the FZD3 and FZD5 receptor-mediated (also affected in L skin) signaling pathway may play a role in axon growth/repulsion (Figure 5 and Supplementary Table S1T). In contrast, we only found DETs of downstream molecules in the NL skin, and these were mostly affecting axon outgrowth (Figure 5.). 


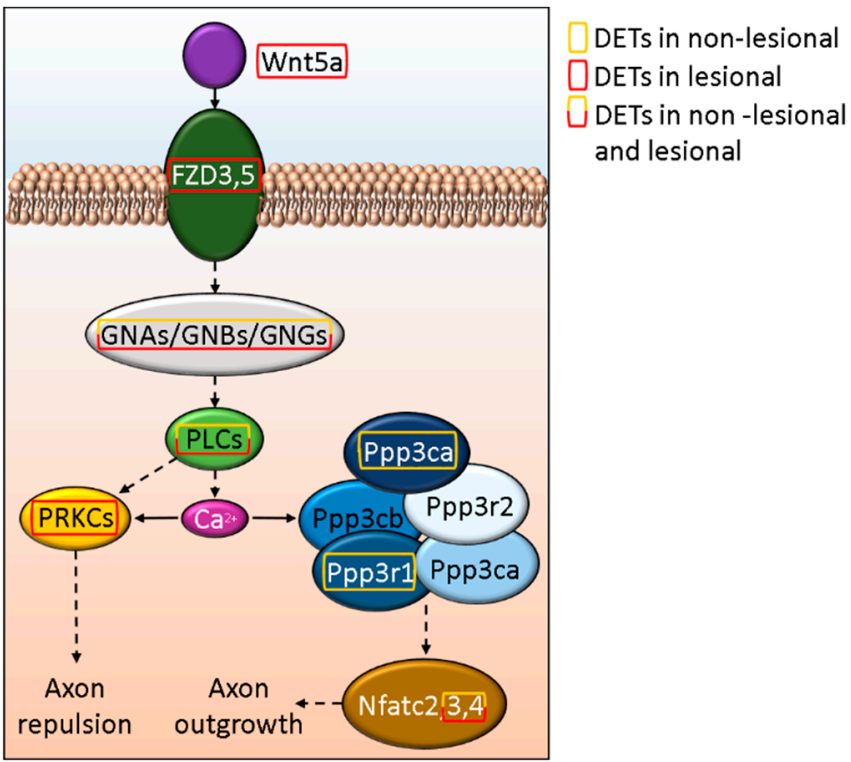

Figure 5. In silico model of the effect of Wnt5a signaling on axon growth and retention in psoriasis.

\section{Discussion}

Psoriasis is a chronic inflammatory skin disease where interleukin (IL)-17 is the major driver of inflammatory responses [62]. Studies, including the imiquimod-induced psoriasislike skin inflammation models in mice [63], suggest that the peripheral nervous system may have a role in the initiation and maintenance of the inflammatory and hyperproliferative responses through the release of neuropeptides [26,30]. Cutaneous nerves can activate dermal dendritic cells' IL-23 production, and IL-23 triggers IL-17 expression and release by T cells [63]. Drugs targeting IL-17 and IL-23 are, as a matter of fact, are some of the most effective drugs available to treat psoriasis $[64,65]$. Therefore, peripheral nervous systemrelated abnormalities could be important to understand the pathomechanism of psoriasis.

During the reanalysis of public RNA-sequencing data, we found that neuritogenesis might be disturbed in psoriatic patients. For example Semaphorin-Plexin signaling cascades regulate various features of neuronal projection formation-related processes [66]. Semaphorins were originally identified as neuronal and axon growth guidance molecules. Today it is clear that the superfamily of semaphorins counting over 20 members of soluble extracellular and cell surface transmembrane signaling proteins, can modulate the development and function of several organs, including the cardiovascular [67], immune [68,69], and the nervous system [70], among others [71,72]. Despite their massive role in innate immune responses and inflammation [73], we have limited data about the semaphorins' involvement in psoriasis pathogenesis [74-76], but no information on axon formation-related processes in the context of this disease. Since neuritogenesis might be affected [77] in psoriasis, it is not surprising that DETs of semaphorins (Semas) were identified in our study, given their clear role in axon guidance. Most of the molecules, like SemaB and SemaF, were implicated in both axon attraction or repulsion [78]. These antagonistic functions may be due to the differences in their local concentrations, and/or the receptor repertoire on the interacting cells. For example, Sema3E stimulates axon growth of PLXND1 and NRP1 expressing neurons, but when PlexinD1 is expressed without NRP1, Sema3E has an opposite effect [79]. In addition, Sema3E interaction with its co-receptor VEGFR2 may also stimulate axon extension [80]. Despite that VEGFR2 was not affected in our analyzed dataset, the expression of other Sema receptors, including NRP1, NRP2, PLXNA3, PLXNB1, PLXNB3, PLXND1, as well as L1CAM and ERBB2 were differentially expressed in psoriatic samples. The decrease in Sema3D could negatively influence both the numbers and the branching of peripheral axons [81]. Interestingly, the expression of this molecule was affected in lesions, which may be a reason why the number of neurites and axonal branching is reduced in 
psoriatic patients [77]. NRP1was suggested to play in the pathomechanism of psoriasis by several studies in context with keratinocyte proliferation and differentiation, angiogenesis and lymphangiogenesis among others (reviewed by Sunhyo Ryu and colleagues [76]).

Class IV semaphorins are thought to be transmembrane proteins [73]. Sema4D presented at the surface of the cells is known to influence axon regeneration, and its overexpression can inhibit neuron myelination [61]. Sema4D is also expressed by various immune cells, including T cells, and could modulate dendritic cell functions [82]. In psoriasis, T cells infiltrate not only to the dermis, where they may interact with dermal dendritic cells, but also the epidermis to contact with Langerhans cells. Sema4D was also suggested to induce keratinocyte mediated inflammatory responses in psoriasis [75]. Moreover, myelination of neurites is the least pronounced in the epidermis, where Sema4D(+) T cells may interrupt the myelination processes, and thereby inhibit axon regeneration. In line with this concept, we found several major myelin-associated proteins [83], including MBP, MPZ, PMP22, and RTN4 with altered expression in psoriatic lesions. RTN4 (also known as NOGOA) is a myelin-associated inhibitor of axon growth and regeneration following nerve injury [84] and may contribute to the reduction of neurites [77] in lesions.

We also found SLIT2 and its receptor ROBO1, previously shown to be expressed by both axons and Schwann cells, and ROBO2 that is mainly expressed by axons in mice [85] in the lesional samples of our dataset. Schwann cell-expressed NTN1, which participates in axon regeneration following nerve injury [86], is also affected in psoriatic lesions. NTN1 can also influence neutrophil, macrophage, and T-cell infiltration [87]. In addition, dendritic cell-originated Sema4A might play a role in the activation of both Th1 and Th17 cells in the neuroinflammatory demyelinating autoimmune disease, multiple sclerosis [88,89]. This molecule is also affected by DETs in psoriatic patients.

In the nervous system, Sema4B plays a role in synapse formation and maintenance and might influence post-synaptic density [90]. We found altered expression of this molecule only in NL skin. In addition, Sema4B could inhibit basophil-mediated Th2 skewing [91] and contributes to the developing Th1/Th2 imbalance in psoriasis [92]. Apart from this, circular SEMA4B RNA may decrease the effect of IL-1 $\beta$ through Wnt signaling [93]. This pathway may also influence axon growth/repulsion via WNT5A (and its receptors FZD3 and FZD5) that we found to be affected in psoriatic lesions which is in line with previous observation [94]. It may also act as a suppressor of axonal regeneration [95], and at the same time, facilitate CXCL12-CXCR4-mediated T-cell infiltration [96], with the latter being known to be important in chronic inflammatory skin diseases [97].

Therefore, we suggest that the dysregulation in 12 different semaphorins and some of their main receptors and co-receptors could contribute to the abnormal neuron projection formation described earlier in psoriasis [77]. Semaphorin signaling could also greatly influence other major hallmarks of psoriasis, for example the innate immune and inflammatory processes [73]. Therefore, our study can highlight an additional angle of the crosstalk between the neuro-immune system, which might be another important factor in the psoriasis pathomechanism, in addition to the neurogenic pro-inflammatory mediators. Our study provides a strong base and novel directions in psoriatic research since due to the discrepancy that differentially expressed mRNAs do not necessarily correlate with protein expression level, therefore future studies are required to analyze these correlations and to validate the cellular association of DETs.

It is important to note that the vast majority of semaphorin signaling cascades, as well as SLIT-ROBO and NTN-DCC signaling, exert their effect through the small GTPase RAC1 [84]. This molecule not only connects the cutaneous nervous system and the immune cells but also keratinocytes, where it can influence proliferation, differentiation, and innate immune processes [98]. Based on these features, RAC1 is likely to be an important molecule in psoriasis.

RAC1 is also known as a Ras-related C3 botulinum toxin substrate 1 , as it is the primary target of botulinum toxin. 
Our results together with previous observations provide an explanation why botulinum toxin treatment of patients could be so effective and argues for its more extensive clinical application in psoriasis therapy.

Supplementary Materials: The following supporting information can be downloaded at: https:/ / www.mdpi.com/article/10.3390/life12010111/s1, Figure S1: In silico model of the potential crosstalk between Sema3-Sema4-Sema5-Sema6 signaling in NL and L psoriatic skin; Figure S2: In silico model of the interaction between Sema4 and Sema7A signaling in NL and L psoriatic skin; Table S1: Peripheral nervous system-associated transcript expression alterations in psoriasis.

Author Contributions: Conceptualization, G.G.; methodology, G.G., E.S. and D.R.; software, G.G., E.S. and D.R.; validation, G.G. and D.R.; formal analysis, G.G. and D.R.; investigation, G.G. and D.R.; resources, G.G. and D.R.; data curation, G.G., E.S. and D.R.; writing-original draft preparation, D.R. and G.G.; writing-review and editing, D.R., E.S., K.S., L.K. and G.G.; visualization, D.R.; supervision, G.G.; project administration, G.G. and D.R.; funding acquisition, G.G. and D.R. All authors have read and agreed to the published version of the manuscript.

Funding: This research was funded by the National Research, Development and Innovation Office of Hungary, GINOP-2.2.1-15-2016-00007, and by the Géza Hetényi (5S 269 A202) research grants. The project also has received funding from the EU's Horizon 2020 research and innovation programme under grant agreement (number 739593). D.R. was also supported by the Gedeon Richter Talentum Foundation (H-1103 Budapest, Gyömrői str. 19-21.).

Institutional Review Board Statement: Not applicable.

Informed Consent Statement: Not applicable.

Data Availability Statement: Only publicly available data was used in the study (Sequence Read Archive, https:/ /www.ncbi.nlm.nih.gov/sra; study ID: SRP035988, SRP050971, and SRP055813). Processed data (differential expression analysis) is provided as supplementary material (Table S1).

Conflicts of Interest: The authors declare no conflict of interest.

\section{References}

1. Chiricozzi, A.; Romanelli, P.; Volpe, E.; Borsellino, G.; Romanelli, M. Scanning the Immunopathogenesis of Psoriasis. Int. J. Mol. Sci. 2018, 19, 179. [CrossRef] [PubMed]

2. Gubán, B.; Vas, K.; Balog, Z.; Manczinger, M.; Bebes, A.; Groma, G.; Szell, M.; Kemény, L.; Batacsorgő, Z. Abnormal regulation of fibronectin production by fibroblasts in psoriasis. Br. J. Dermatol. 2015, 174, 533-541. [CrossRef]

3. Szlavicz, E.; Szabo, K.; Groma, G.; Bata-Csorgo, Z.; Pagani, F.; Kemény, L.; Szell, M. Splicing factors differentially expressed in psoriasis alter mRNA maturation of disease-associated EDA ${ }^{+}$fibronectin. Mol. Cell. Biochem. 2017, 436, 189-199. [CrossRef] [PubMed]

4. Eyre, R.W.; Krueger, G.G. Response to injury of skin involved and uninvolved with psoriasis, and its relation to disease activity: Koebner and'reverse'Koebner reactions. Br. J. Dermatol. 1982, 106, 153-159. [CrossRef]

5. Gudjonsson, J.E.; Ding, J.; Li, X.; Nair, R.P.; Tejasvi, T.; Qin, Z.; Ghosh, D.; Aphale, A.; Gumucio, D.L.; Voorhees, J.J.; et al. Global Gene Expression Analysis Reveals Evidence for Decreased Lipid Biosynthesis and Increased Innate Immunity in Uninvolved Psoriatic Skin. J. Investig. Dermatol. 2009, 129, 2795-2804. [CrossRef] [PubMed]

6. Szabó, K.; Bata-Csörgő, Z.; Dallos, A.; Bebes, A.; Francziszti, L.; Dobozy, A.; Kemény, L.; Széll, M. Regulatory Networks Contributing to Psoriasis Susceptibility. Acta Derm. Venereol. 2014, 94, 380-385. [CrossRef]

7. Oh, S.; Chung, H.; Chang, S.; Lee, S.-H.; Seok, S.H.; Lee, H. Effect of Mechanical Stretch on the DNCB-induced Proinflammatory Cytokine Secretion in Human Keratinocytes. Sci. Rep. 2019, 9, 5156. [CrossRef]

8. Baumbauer, K.M.; DeBerry, J.; Adelman, P.; Miller, R.H.; Hachisuka, J.; Lee, K.H.; Ross, S.E.; Koerber, H.R.; Davis, B.; Albers, K. Keratinocytes can modulate and directly initiate nociceptive responses. eLife 2015, 4, 09674. [CrossRef] [PubMed]

9. Yosipovitch, G.; Chan, Y.; Tay, Y.; Goh, C. Thermosensory abnormalities and blood flow dysfunction in psoriatic skin. Br. J. Dermatol. 2003, 149, 492-497. [CrossRef]

10. Sulzberger, M.B. BUGS. Arch. Dermatol. 1971, 104, 220. [CrossRef]

11. Weiner, S.R.; Bassett, L.W.; Reichman, R.P. Protective effect of poliomyelitis on psoriatic arthritis. Arthritis Rheum. 1985, 28, 703-706. [CrossRef]

12. Farber, E.M.; Lanigan, S.W.; Boer, J. The Role of Cutaneous Sensory Nerves in the Maintenance of Psoriasis. Int. J. Dermatol. 1990, 29, 418-420. [CrossRef] [PubMed]

13. Raychaudhuri, S.P.; Farber, E.M. Are sensory nerves essential for the development of psoriatic lesions? J. Am. Acad. Dermatol. 1993, 28, 488-489. [CrossRef] 
14. Joseph, T.; Kurian, J.; Warwick, D.; Friedmann, P. Unilateral remission of psoriasis following traumatic nerve palsy. Br. J. Dermatol. 2005, 152, 185-186. [PubMed]

15. Kane, D.; Lockhart, J.C.; Balint, P.V.; Mann, C.; Ferrell, W.R.; McInnes, I. Protective effect of sensory denervation in inflammatory arthritis (evidence of regulatory neuroimmune pathways in the arthritic joint). Ann. Rheum. Dis. 2005, 64, 325-327. [CrossRef]

16. Kecici, A.S.; Göktay, F.; Tutkavul, K.; Günes, P.; Yasar, S. Unilateral improvement of nail psoriasis with denervation injury. Clin. Exp. Dermatol. 2018, 43, 339-341. [CrossRef]

17. Sowell, J.K.; Pippenger, M.A.; Crowe, M.J. Psoriasis Contralateral to Hemiparesis Following Cerebrovascular Accident. Int. J Dermatol. 1993, 32, 598-599. [CrossRef]

18. Veale, D.; Farrell, M.; FitzGerald, O. Mechanism of joint sparing in a patient with unilateral psoriatic arthritis and a longstanding hemiplegia. Rheumatology 1993, 32, 413-416. [CrossRef]

19. Stratigos, A.J.; Katoulis, A.K.; Stavrianeas, N.G. Spontaneous clearing of psoriasis after stroke. J. Am. Acad. Dermatol. 1998, 38, 768-770. [CrossRef]

20. Qin, B.; Sun, C.; Chen, L.; Wang, S.; Yang, J.; Xie, Z.; Shen, Z. The nerve injuries attenuate the persistence of psoriatic lesions. J. Dermatol. Sci. 2021, 102, 85-93. [CrossRef]

21. Zhu, T.H.; Nakamura, M.; Farahnik, B.; Abrouk, M.; Lee, K.; Singh, R.; Gevorgyan, A.; Koo, J.; Bhutani, T. The Role of the Nervous System in the Pathophysiology of Psoriasis: A Review of Cases of Psoriasis Remission or Improvement Following Denervation Injury. Am. J. Clin. Dermatol. 2016, 17, 257-263. [CrossRef]

22. González, C.; Franco, M.; Londoño, A.; Valenzuela, F. Breaking paradigms in the treatment of psoriasis: Use of botulinum toxin for the treatment of plaque psoriasis. Dermatol. Ther. 2020, 33, 14319. [CrossRef]

23. Aschenbeck, K.A.; Hordinsky, M.K.; Kennedy, W.R.; Wendelschafer-Crabb, G.; Ericson, M.E.; Kavand, S.; Bertin, A.; Dykstra, D.D.; Panoutsopoulou, I.G. Neuromodulatory treatment of recalcitrant plaque psoriasis with onabotulinumtoxinA. J. Am. Acad. Dermatol. 2018, 79, 1156-1159. [CrossRef]

24. Amalia, S.N.; Uchiyama, A.; Baral, H.; Inoue, Y.; Yamazaki, S.; Fujiwara, C.; Sekiguchi, A.; Yokoyama, Y.; Ogino, S.; Torii, R.; et al Suppression of neuropeptide by botulinum toxin improves imiquimod-induced psoriasis-like dermatitis via the regulation of neuroimmune system. J. Dermatol. Sci. 2021, 101, 58-68. [CrossRef]

25. Farber, E.M.; Nickoloff, B.J.; Recht, B.; Fraki, J.E. Stress, symmetry, and psoriasis: Possible role of neuropeptides. J. Am. Acad. Dermatol. 1986, 14, 305-311. [CrossRef]

26. Saraceno, R.; Kleyn, C.E.; Terenghi, G.; Griffiths, C.E.M. The role of neuropeptides in psoriasis. Br. J. Dermatol. 2006, 155, 876-882. [CrossRef]

27. Legat, F.J.; Griesbacher, T.; Schicho, R.; Althuber, P.; Schuligoi, R.; Kerl, H.; Wolf, P. Repeated subinflammatory ultraviolet B irradiation increases substance $\mathrm{P}$ and calcitonin gene-related peptide content and augments mustard oil-induced neurogenic inflammation in the skin of rats. Neurosci. Lett. 2002, 329, 309-313. [CrossRef]

28. Dias, M.P.; Newton, D.J.; McLeod, G.A.; Belch, J.J.F.; Khan, F. Vasoactive properties of calcitonin gene-related peptide in Human Skin. Int. Angiol. 2011, 30, 424-428. [PubMed]

29. Raychaudhuri, S.P.; Raychaudhuri, S.K. Role of NGF and neurogenic inflammation in the pathogenesis of psoriasis. Prog. Brain Res. 2004, 146, 433-437.

30. Glinski, W.; Brodecka, H.; Glinska-Ferenz, M.; Kowalski, D. Neuropeptides in psoriasis: Possible role of beta-endorphin in the pathomechanism of the disease. Int. J. Dermatol. 1994, 33, 356-360. [CrossRef] [PubMed]

31. Naukkarinen, A.; Nickoloff, B.J.; Farber, E.M. Quantification of Cutaneous Sensory Nerves and Their Substance P Content in Psoriasis. J. Investig. Dermatol. 1989, 92, 126-129. [CrossRef]

32. Siiskonen, H.; Harvima, I. Mast Cells and Sensory Nerves Contribute to Neurogenic Inflammation and Pruritus in Chronic Skin Inflammation. Front. Cell. Neurosci. 2019, 13, 422. [CrossRef]

33. Choi, J.E.; Di Nardo, A. Skin neurogenic inflammation. Semin. Immunopathol. 2018, 40, 249-259. [CrossRef]

34. Szepietowski, J.C.; Reich, A. Itch in Psoriasis Management. Diagnosis and Therapy of Tattoo Complications. Itch Manag. Clin. Pract. 2016, 50, 102-110.

35. Szepietowski, J.; Reich, A. Pruritus in psoriasis: An update. Eur. J. Pain 2015, 20, 41-46. [CrossRef] [PubMed]

36. Tsianakas, A.; Mrowietz, U. Pruritus bei Psoriasis. Der Hautarzt 2016, 67, 601-605. [CrossRef]

37. Arck, P.; Paus, R. From the Brain-Skin Connection: The Neuroendocrine-Immune Misalliance of Stress and Itch. Neuroimmunomodulation 2006, 13, 347-356. [CrossRef]

38. Leon, A.; Rosen, J.D.; Hashimoto, T.; Fostini, A.C.; Paus, R.; Yosipovitch, G. Itching for an answer: A review of potential mechanisms of scalp itch in psoriasis. Exp. Dermatol. 2019, 28, 1397-1404. [CrossRef]

39. Pithadia, D.J.; Reynolds, K.A.; Lee, E.B.; Wu, J.J. Psoriasis-associated cutaneous pain: Etiology, assessment, impact, and management. J. Dermatol. Treat. 2018, 30, 435-440. [CrossRef]

40. Li, Y.; Lin, P.; Wang, S.; Li, S.; Wang, R.; Yang, L.; Wang, H. Quantitative analysis of differentially expressed proteins in psoriasis vulgaris using tandem mass tags and parallel reaction monitoring. Clin. Proteom. 2020, 17, 30. [CrossRef] [PubMed]

41. Szél, E.; Bozó, R.; Hunyadi-Gulyás, É.; Manczinger, M.; Szabó, K.; Kemény, L.; Bata-Csörgő, Z.; Groma, G. Comprehensive Proteomic Analysis Reveals Intermediate Stage of Non-Lesional Psoriatic Skin and Points out the Importance of Proteins Outside this Trend. Sci. Rep. 2019, 9, 1382. [CrossRef] 
42. Manczinger, M.; Kemeny, L. Novel Factors in the Pathogenesis of Psoriasis and Potential Drug Candidates Are Found with Systems Biology Approach. PLoS ONE 2013, 8, e80751. [CrossRef]

43. Li, B.; Tsoi, L.C.; Swindell, W.R.; Gudjonsson, J.E.; Tejasvi, T.; Johnston, A.; Ding, J.; Stuart, P.E.; Xing, X.; Kochkodan, J.J.; et al Transcriptome Analysis of Psoriasis in a Large Case-Control Sample: RNA-Seq Provides Insights into Disease Mechanisms. J. Investig. Dermatol. 2014, 134, 1828-1838. [CrossRef] [PubMed]

44. Tsoi, L.C.; Iyer, M.K.; Stuart, P.E.; Swindell, W.R.; Gudjonsson, J.E.; Tejasvi, T.; Sarkar, M.K.; Li, B.; Ding, J.; Voorhees, J.J.; et al. Analysis of long non-coding RNAs highlights tissue-specific expression patterns and epigenetic profiles in normal and psoriatic skin. Genome Biol. 2015, 16, 24. [CrossRef]

45. Tsoi, L.C.; Stuart, P.E.; Tian, C.; Gudjonsson, J.E.; Das, S.; Zawistowski, M.; Ellinghaus, E.; Barker, J.N.; Chandran, V.; Dand, N.; et al. Large scale meta-analysis characterizes genetic architecture for common psoriasis associated variants. Nat. Commun. 2017, 8 , 15382. [CrossRef] [PubMed]

46. Zhou, F.; Wang, W.; Shen, C.; Li, H.; Zuo, X.; Zheng, X.; Yue, M.; Zhang, C.; Yu, L.; Chen, M.; et al. Epigenome-Wide Association Analysis Identified Nine Skin DNA Methylation Loci for Psoriasis. J. Investig. Dermatol. 2016, 136, 779-787. [CrossRef] [PubMed]

47. Calautti, E.; Avalle, L.; Poli, V. Psoriasis: A STAT3-Centric View. Int. J. Mol. Sci. 2018, 19, 171. [CrossRef]

48. $\quad$ Liang, Y.; Tsoi, L.C.; Xing, X.; Beamer, M.A.; Swindell, W.R.; Sarkar, M.; Berthier, C.C.; Stuart, P.E.; Harms, P.W.; Nair, R.P.; et al. A gene network regulated by the transcription factor VGLL3 as a promoter of sex-biased autoimmune diseases. Nat. Immunol. 2017, 18, 152-160. [CrossRef]

49. Sahoo, P.; Smith, D.S.; Perrone-Bizzozero, N.; Twiss, J.L. Axonal mRNA transport and translation at a glance. J. Cell Sci. 2018, 131, jcs196808. [CrossRef]

50. Costa, I.D.; Buchanan, C.N.; Zdradzinski, M.D.; Sahoo, P.K.; Smith, T.P.; Thames, E.; Kar, A.N.; Twiss, J.L. The functional organization of axonal mRNA transport and translation. Nat. Rev. Neurosci. 2021, 22, 77-91. [CrossRef]

51. Bray, N.L.; Pimentel, H.; Melsted, P.; Pachter, H.P.L. Near-optimal probabilistic RNA-seq quantification. Nat. Biotechnol. 2016, 34, 525-527. [CrossRef]

52. Harrow, J.; Frankish, A.; Gonzalez, J.M.; Tapanari, E.; Diekhans, M.; Kokocinski, F.; Aken, B.L.; Barrell, D.; Zadissa, A.; Searle, S.; et al. Gencode: The reference human genome annotation for The ENCODE Project. Genome Res. 2012, 22, 1760-1774. [CrossRef]

53. Soneson, C.; Love, M.I.; Robinson, M.D. Differential analyses for RNA-seq: Transcript-level estimates improve gene-level inferences. F1000Research 2016, 4, 1521. [CrossRef]

54. McCarthy, D.J.; Chen, Y.; Smyth, G.K. Differential expression analysis of multifactor RNA-Seq experiments with respect to biological variation. Nucleic Acids Res. 2012, 40, 4288-4297. [CrossRef] [PubMed]

55. Schwämmle, V.; León, I.R.; Jensen, O.N. Assessment and Improvement of Statistical Tools for Comparative Proteomics Analysis of Sparse Data Sets with Few Experimental Replicates. J. Proteome Res. 2013, 12, 3874-3883. [CrossRef]

56. Ritchie, M.; Phipson, B.; Wu, D.; Hu, Y.; Law, C.W.; Shi, W.; Smyth, G.K. limma powers differential expression analyses for RNA-sequencing and microarray studies. Nucleic Acids Res. 2015, 43, e47. [CrossRef] [PubMed]

57. Liu, R.; Holik, A.Z.; Su, S.; Jansz, N.; Chen, K.; Leong, H.S.; Blewitt, M.; Asselin-Labat, M.-L.; Smyth, G.; Ritchie, M.E. Why weight? Modelling sample and observational level variability improves power in RNA-seq analyses. Nucleic Acids Res. 2015, 43, e97. [CrossRef]

58. Berchtold, W. Comparison of the Kastenbaum-Bowman test and Fisher's exact test. Archiv fur Genetik 1975, $48,151-157$.

59. Eden, E.; Navon, R.; Steinfeld, I.; Lipson, D.; Yakhini, Z. GOrilla: A tool for discovery and visualization of enriched GO terms in ranked gene lists. BMC Bioinform. 2009, 10, 48. [CrossRef] [PubMed]

60. Ferreira, J.A. The Benjamini-Hochberg method in the case of discrete test statistics. Int. J. Biostat. 2007, 3, 11. [CrossRef]

61. Zhang, H.-L.; Wang, J.; Tang, L. Sema4D Knockdown in Oligodendrocytes Promotes Functional Recovery After Spinal Cord Injury. Cell Biophys. 2013, 68, 489-496. [CrossRef]

62. Furue, K.; Ito, T.; Tsuji, G.; Kadono, T.; Furue, M. Psoriasis and the TNF/IL23/IL17 axis. Ital. J. Dermatol. Venereol. 2019, 154, 418-424. [CrossRef]

63. Riol-Blanco, L.; Ordovas-Montanes, J.; Perro, M.; Naval, E.; Thiriot, A.; Alvarez, D.; Paust, S.; Wood, J.N.; Von Andrian, U.H. Nociceptive sensory neurons drive interleukin-23-mediated psoriasiform skin inflammation. Nat. Cell Biol. 2014, 510, 157-161. [CrossRef] [PubMed]

64. Dattola, A.; Silvestri, M.; Tamburi, F.; Amoruso, G.F.; Bennardo, L.; Nisticò, S.P. Emerging role of anti-IL23 in the treatment of psoriasis: When humanized is very promising. Dermatol. Ther. 2020, 33, e14504. [CrossRef]

65. Amoruso, G.; Nisticò, S.; Iannone, L.; Russo, E.; Rago, G.; Patruno, C.; Bennardo, L. Ixekizumab May Improve Renal Function in Psoriasis. Health 2021, 9, 543. [CrossRef] [PubMed]

66. Worzfeld, T.; Offermanns, S. Semaphorins and plexins as therapeutic targets. Nat. Rev. Drug Discov. 2014, 13, 603-621. [CrossRef] [PubMed]

67. Adams, R.H.; Eichmann, A. Axon Guidance Molecules in Vascular Patterning. Cold Spring Harb. Perspect. Biol. 2010,2 , a001875. [CrossRef]

68. Suzuki, K.; Kumanogoh, A.; Kikutani, H. Semaphorins and their receptors in immune cell interactions. Nat. Immunol. 2007, 9 , 17-23. [CrossRef] [PubMed]

69. Kumanogoh, A.; Kikutani, H. Immunological functions of the neuropilins and plexins as receptors for semaphorins. Nat. Rev. Immunol. 2013, 13, 802-814. [CrossRef] [PubMed] 
70. Yoshida, Y. Semaphorin Signaling in Vertebrate Neural Circuit Assembly. Front. Mol. Neurosci. 2012, 5, 71. [CrossRef]

71. Messina, A.; Ferraris, N.; Wray, S.; Cagnoni, G.; Donohue, D.E.; Casoni, F.; Kramer, P.R.; Derijck, A.A.; Adolfs, Y.; Fasolo, A.; et al. Dysregulation of Semaphorin7A/ $\beta 1$-integrin signaling leads to defective GnRH-1 cell migration, abnormal gonadal development and altered fertility. Hum. Mol. Genet. 2011, 20, 4759-4774. [CrossRef]

72. Giacobini, P.; Prevot, V. Semaphorins in the development, homeostasis and disease of hormone systems. Semin. Cell Dev. Biol. 2013, 24, 190-198. [CrossRef] [PubMed]

73. Kanth, S.M.; Gairhe, S.; Torabi-Parizi, P. The Role of Semaphorins and Their Receptors in Innate Immune Responses and Clinical Diseases of Acute Inflammation. Front. Immunol. 2021, 12, 1610. [CrossRef] [PubMed]

74. Sabag, A.D.; Dias-Polak, D.; Bejar, J.; Sheffer, H.; Bergman, R.; Vadasz, Z. Altered expression of regulatory molecules in the skin of psoriasis. Immunol. Res. 2018, 66, 649-654. [CrossRef] [PubMed]

75. Zhang, C.; Xiao, C.; Dang, E.; Cao, J.; Zhu, Z.; Fu, M.; Yao, X.; Liu, Y.; Jin, B.; Wang, G.; et al. CD100-Plexin-B2 Promotes the Inflammation in Psoriasis by Activating NF-кB and the Inflammasome in Keratinocytes. J. Investig. Dermatol. 2018, 138, 375-383. [CrossRef]

76. Ryu, S.; Broussard, L.; Youn, C.; Song, B.; Norris, D.; Armstrong, C.A.; Kim, B.; Song, P.I. Therapeutic Effects of Synthetic Antimicrobial Peptides, TRAIL and NRP1 Blocking Peptides in Psoriatic Keratinocytes. Chonnam. Med. J. 2019, 55, 75-85. [CrossRef] [PubMed]

77. Casper, M. 3-Dimensional Imaging of Cutaneous Nerve Endings. J. Investig. Dermatol. 2019, 139, 999-1001. [CrossRef]

78. Julien, F.; Bechara, A.; Fiore, R.; Nawabi, H.; Zhou, H.; Hoyo-Becerra, C.; Bozon, M.; Rougon, G.; Grumet, M.; Püschel, A.W.; et al. Dual Functional Activity of Semaphorin 3B Is Required for Positioning the Anterior Commissure. Neuron 2005, 48, 63-75. [CrossRef]

79. Chauvet, S.; Cohen, S.; Yoshida, Y.; Fekrane, L.; Livet, J.; Gayet, O.; Segu, L.; Buhot, M.-C.; Jessell, T.M.; Henderson, C.; et al. Gating of Sema3E/PlexinD1 Signaling by Neuropilin-1 Switches Axonal Repulsion to Attraction during Brain Development. Neuron 2007, 56, 807-822. [CrossRef]

80. Bellon, A.; Luchino, J.; Haigh, K.; Rougon, G.; Haigh, J.; Chauvet, S.; Mann, F. VEGFR2 (KDR/Flk1) Signaling Mediates Axon Growth in Response to Semaphorin 3E in the Developing Brain. Neuron 2010, 66, 205-219. [CrossRef]

81. Liu, Y.; Halloran, M.C. Central and Peripheral Axon Branches from One Neuron Are Guided Differentially by Semaphorin3D and Transient Axonal Glycoprotein-1. J. Neurosci. 2005, 25, 10556-10563. [CrossRef]

82. Simona, M.; Antonio, P.; Massimo, B.; Alfonso, C. Neuronal Semaphorins Regulate a Primary Immune Response. Curr. Neurovasc. Res. 2006, 3, 295-305.

83. Siems, S.B.; Jahn, O.; Eichel, M.; Kannaiyan, N.; Wu, L.M.N.; Sherman, D.L.; Kusch, K.; Hesse, D.; Jung, R.B.; Fledrich, R.; et al. Proteome profile of peripheral myelin in healthy mice and in a neuropathy model. eLife 2020, 9, 51406. [CrossRef]

84. Kalpachidou, T.; Spiecker, L.; Kress, M.; Quarta, S. Rho GTPases in the Physiology and Pathophysiology of Peripheral Sensory Neurons. Cells 2019, 8, 591. [CrossRef]

85. Carr, L.; Parkinson, D.B.; Dun, X.-P. Expression patterns of Slit and Robo family members in adult mouse spinal cord and peripheral nervous system. PLoS ONE 2017, 12, e0172736. [CrossRef] [PubMed]

86. Dun, X.-P.; Parkinson, D.B. Role of Netrin-1 Signaling in Nerve Regeneration. Int. J. Mol. Sci. 2017, 18, 491. [CrossRef] [PubMed]

87. Boneschansker, L.; Nakayama, H.; Eisenga, M.; Wedel, J.; Klagsbrun, M.; Irimia, D.; Briscoe, D.M. Netrin-1 Augments Chemokinesis in CD4 ${ }^{+}$T Cells In Vitro and Elicits a Proinflammatory Response In Vivo. J. Immunol. 2016, 197, 1389-1398. [CrossRef] [PubMed]

88. Nakatsuji, Y.; Okuno, T.; Moriya, M.; Sugimoto, T.; Kinoshita, M.; Takamatsu, H.; Nojima, S.; Kimura, T.; Kang, S.; Ito, D.; et al. Elevation of Sema4A Implicates Th Cell Skewing and the Efficacy of IFN- $\beta$ Therapy in Multiple Sclerosis. J. Immunol. 2012, 188, 4858-4865. [CrossRef] [PubMed]

89. Koda, T.; Namba, A.; Kinoshita, M.; Nakatsuji, Y.; Sugimoto, T.; Sakakibara, K.; Tada, S.; Shimizu, M.; Yamashita, K.; Takata, K.; et al. Sema4A is implicated in the acceleration of Th17 cell-mediated neuroinflammation in the effector phase. J. Neuroinflamm. 2020, 17, 82-89. [CrossRef] [PubMed]

90. Burkhardt, C.; Müller, M.; Badde, A.; Garner, C.C.; Gundelfinger, E.D.; Püschel, A.W. Semaphorin 4B interacts with the postsynaptic density protein PSD-95/SAP90 and is recruited to synapses through a C-terminal PDZ-binding motif. FEBS Lett. 2005, 579, 3821-3828. [CrossRef]

91. Nakagawa, Y.; Takamatsu, H.; Okuno, T.; Kang, S.; Nojima, S.; Kimura, T.; Kataoka, T.R.; Ikawa, M.; Toyofuku, T.; Katayama, I.; et al. Identification of Semaphorin $4 \mathrm{~B}$ as a Negative Regulator of Basophil-Mediated Immune Responses. J. Immunol. 2011, 186, 2881-2888. [CrossRef]

92. Zhu, K.; Ye, J.; Wu, M.; Cheng, H. Expression of Th1 and Th2 cytokine-associated transcription factors, T-bet and GATA-3, in peripheral blood mononuclear cells and skin lesions of patients with psoriasis vulgaris. Arch. Dermatol. Res. 2010, 302, 517-523. [CrossRef] [PubMed]

93. Wang, X.; Wang, B.; Zou, M.; Li, J.; Lü, G.; Zhang, Q.; Liu, F.; Lu, C. CircSEMA4B targets miR-431 modulating IL-1ß-induced degradative changes in nucleus pulposus cells in intervertebral disc degeneration via Wnt pathway. Biochim. Biophys. Acta BBA Mol. Basis Dis. 2018, 1864, 3754-3768. [CrossRef] [PubMed]

94. Romanowska, M.; Evans, A.; Kellock, D.; Bray, S.E.; McLean, K.; Donandt, S.; Foerster, J. Wnt5a Exhibits Layer-Specific Expression in Adult Skin, Is Upregulated in Psoriasis, and Synergizes with Type 1 Interferon. PLoS ONE 2009, 4, e5354. [CrossRef] [PubMed] 
95. Clark, C.E.J.; Liu, Y.; Cooper, H.M. The Yin and Yang of Wnt/Ryk axon guidance in development and regeneration. Sci. China Life Sci. 2014, 57, 366-371. [CrossRef] [PubMed]

96. Ghosh, M.C.; Collins, G.D.; Vandanmagsar, B.; Patel, K.; Brill, M.; Carter, A.; Lustig, A.; Becker, K.G.; Wood, W.W.; Emeche, C.D.; et al. Activation of Wnt5A signaling is required for CXC chemokine ligand 12-mediated T-cell migration. Blood 2009, 114, 1366-1373. [CrossRef]

97. Zgraggen, S.; Huggenberger, R.; Kerl, K.; Detmar, M. An Important Role of the SDF-1/CXCR4 Axis in Chronic Skin In-flammation. PLOS ONE 2014, 9, e93665.

98. Winge, M.C.; Ohyama, B.; Dey, C.N.; Boxer, L.; Li, W.; Ehsani-Chimeh, N.; Truong, A.K.; Wu, D.; Armstrong, A.W.; Makino, T.; et al. RAC1 activation drives pathologic interactions between the epidermis and immune cells. J. Clin. Investig. 2016, 126, 2661-2677. [CrossRef] 